\title{
Satisfaction of Hotel Business Regarding Educational Hotel Trip Survey: A Case Study of Chatrium Hotel Riverside Bangkok
}

\author{
Samart Plangpramool, Kumutinee Jaroenrat \\ Burapha University International College (BUUIC), Chonburi, Thailand
}

\begin{abstract}
Nowadays, there are so many educational hotel trip surveys done by many institutions that offer hospitality and hotel management programs which are compulsory for students to learn from the real life situations when they visit the hotel properties (or) also called "departmental operating visits". Regarding this, when they visit, they require hotel staff to facilitate and be involved in the process of visiting while they are still working. Therefore, in order to know how the institutions should manage the program for visits and not to interrupt the process of working which is done by hotel staff, this research will find out details in order to have a win-win situation between both educational and hotel sectors. The research focuses only on Burapha University International College (BUUIC) students (Tourism \& Hotel Major) who visited Chatrium Hotel Riverside Bangkok on an educational hotel trip and also frontline staffs and management team of Chatrium Hotel Riverside Bangkok. It will particularly examine frontline staffs and management team about their satisfaction of the program designed by BUUIC. The information will be collected through 50 respondents after administering a questionnaire. Therefore, 50 staff at Chatrium Hotel Riverside Bangkok will be interviewed to understand the relationship between attributes and satisfaction. This research would facilitate both institutions and hotels by investigating the perception of hotel staffs who are already involved in the educational hotel trip. Therefore, the findings will measure the satisfaction of hotel staff and the results would be useful for the Hotel Industry and other accommodation/restaurants and especially for institutions to make an effective program.
\end{abstract}

Keywords: educational hotel trip, departmental operating visits, attributes

\section{Introduction}

Satisfaction is an essential indicator of the past, present, and future performance (Oliver, 1999). Understanding satisfaction has become vital to businesses since it often serves as a key driver of repeat purchase behavior (Wells \& Prensky, 1996). It is evident that higher satisfaction results in higher than normal market share growth, the ability to charge a higher price, improved customer loyalty with a strong link to increased profitability, and reduced transaction costs (Fornell, 1992). On the other hand, measurement of service quality allows comparing before and after changes, identifying the quality-related problems, and establishing clear standards for service delivery. It is claimed that high service quality enhances satisfaction,

Samart Plangpramool, Ph.D. (Candidate), Full-time Instructor and Researcher in Tourism and Hotel Management, Burapha University International College (BUUIC).

Kumutinee Jaroenrat, Ed.D., Full-time Instructor and Researcher in Human Resource Development in Hospitality Industry, Burapha University International College (BUUIC).

Correspondence concerning this article should be addressed to Samart Plangpramool, Burapha University International College (BUUIC), 169 Longhad-Bangsean Road, T.Seansook A.Muang Chonburi 20131, Thailand. E-mail: birdd8@yahoo.com. 
increases market share, and enhances profitability of organizations (Hoffman \& Bateson, 1997). Hence, theories mentioned above are applicable to this research which finding out the satisfaction of hotel business on the educational hotel trip which is organized by Burapha University International College (BUUIC) in order to figure out the opinions of the management of this hotel property (Chatrium Hotel Riverside Bangkok) and to measure their level of satisfaction.

Therefore, the intent of this research; the satisfaction of hotel business regarding educational hotel trip survey: a case study of Chatrium Hotel Riverside Bangkok is to identify the educational hotel trip program which influenced the opinions of the frontline staffs and management team of Chatrium Hotel Riverside Bangkok. The common purpose of this research is to examine for matching between what is the frontline staffs and management team of this hotel property, Chatrium Hotel Riverside Bangkok thought that it should be organize in future on educational hotel trip versus this program the actual one which just been operated in order to make judgments regarding the opinions on the level of satisfaction of the hotel staffs to make suggestions for improvement.

\section{Research Questions}

- To find out the entrepreneur's aspects on the most positive parts of the education hotel trip program;

- To find out the entrepreneur's aspects on the least positive parts of the education hotel trip program;

- To find out the entrepreneur's aspects on the areas that should be improved of the education hotel trip program.

\section{Research Objectives}

We intend to address and answer on satisfaction of hotel business regarding educational hotel trip as following questions:

- This educational hotel trip program of Chatrium Hotel Riverside Bangkok has an appropriated schedule (Date and Time);

- The content of the educational hotel trip program of Chatrium Hotel Riverside Bangkok is interesting;

- This educational hotel trip program of Chatrium Hotel Riverside Bangkok makes interesting contributions to the hotel;

- The levels of satisfaction in each attributes of the hotel staffs at Chatrium Hotel Riverside Bangkok;

- The teamwork of this program, the cooperation between Chatrium Hotel Riverside Bangkok and Burapha University International College (BUUIC);

- Overall satisfaction of the hotel staffs at Chatrium Hotel Riverside Bangkok.

\section{Scope and Limitations of the Study}

The research only focuses on frontline staff and management team of Chatrium Hotel Riverside Bangkok who involved in this educational hotel trip. Particularly, examine the frontline staff and management team of Chatrium Hotel Riverside Bangkok on their satisfaction of the program designed by the Department of Tourism and Hotel Management, Burapha University International College (BUUIC).

The frontline staff are from the main functions of the hotel property includes: Room Division, Food and Beverage, Housekeeping, etc.. For the management includes: Director of Human Resources, Director of Sales and Marketing, Director of Food and Beverage, Director of Rooms, Director of Finance, Director of 
Housekeeping (Executive Housekeeper), and Department Managers.

\section{Significance of the Study}

This research would facilitate both educational institutions and hotels by investigating the satisfactions of frontline staff and management team of Chatrium Hotel Riverside Bangkok who have already involved in this educational hotel trip. Therefore, the findings will measure the satisfaction of frontline staffs and management team of Chatrium Hotel Riverside Bangkok and the results would be useful for Hotel Industry and other accommodations/restaurants and especially educational institutions for making effective program.

\section{Literature Review}

\section{Satisfaction}

Satisfaction has been described in so many ways. Oliver's (1981) description tends to provide a clear meaning "the emotional reaction following a disconfirmation experience which acts on the base attitude level and is consumption specific". Furthermore, Locke (1976) defined that satisfaction as "a pleasurable or positive emotional state resulting from the appraisal of one's experience”. Byrne (2001) mentioned that satisfaction is a theoretical construct that cannot be observed directly which similar to Diener and Suh (1997), satisfaction constitutes positive and negative feelings. Satisfaction is cognitive judgments and evaluations that an individual makes about his or her life's experiences.

Oliver (1981) emphasized two core elements of satisfaction which are included expectation and its confirmation process. For example, finding a radio station to listen to in the car by Kinicki and Kreitner (2009), they mentioned that you cannot optimize because it is impossible to listen to all stations at the same time. Thus you stop searching for a station when you find one playing a song you like or do not mind to hearing. Therefore, satisfaction is a chosen solution that meets some minimum qualifications, one that is "good enough" which is opposed to optimal. It is the ways to respond to problems and opportunities rather than trying to make the optimal decision (Jones \& George, 2011). Besides, Lee and Trail (2011) noticed that the status of one's satisfaction with a product is determined when relative product attributes are compared and appraised in accordance with one's prior experience with the product. It is concluded that satisfaction is some minimum qualifications, one that is good enough of something.

Satisfaction is a theoretical construct that cannot be observed directly, and it must be measured indirectly based on operational definitions (Byrne, 2001). According to Neugarten, Havighurst, and Tobin (1961), theoretical framework provided an operational definition of the latent variable of life satisfaction, which consists of the following five observed variables: zest versus apathy, resolution and fortitude, congruence between desired and achieved goals, self-concept, and mood tone. A review of the literature indicates a general satisfaction by members or people who involved in the program, so this research is focusing on the satisfaction of hotel business regarding educational hotel trip which are date, time, content, teamwork's climate, and flexibility of the educational trip.

\section{Educational Trip}

Johnson (2010) mentioned about the study trip that students are not learning effectively by using traditional textbooks and approaches in the classroom. The classroom environment does not promote sufficient engagement with the content. There is a need to look outside the classroom for other resources that can enhance curriculum effectiveness. While often supplemental text materials are used by educators to present information, 
the engagement and excitement of student-centered learning is often lost.

Therefore, the educational hotel trip or departmental operating visit should be a properly planned, well-conducted, and carefully supervised fieldtrip which is a very vital part of the curriculum of any classroom. To be effective, a field trip must not be a spur-of-the-moment affair, it must grow out of the regular learning activities of the students.

\section{Methodology}

However, we did interviews of frontline staff and management team of Chatrium Hotel Riverside Bangkok who involved in this educational hotel trip by distributing a questionnaire. We distributed 50 questionnaires and tabulated results from the 50 questionnaires which had been completed. The questionnaires were distributed and filled in after the trip on 12th of March, 2012.

We chose Chatrium Hotel Riverside Bangkok as a destination for our educational hotel trip and departmental operating visits because it is a brand new hotel located on the banks of the majestic Chao Phraya River with the cultural and historical hub of Bangkok at its doorsteps, the 5-star Chatrium Hotel Riverside Bangkok offers a premium choice by blending spacious yet luxurious contemporary accommodation with warm and friendly Thai hospitality. Whether for business, leisure, meetings, or just simply pleasure, our ability to tailor our products and services to your needs will certainly create "a remarkable experience”. Chatrium Hotel Riverside Bangkok considered being an exclusive location. The magic, mystery, and charm of the Chao Phraya River that flows through the inner city of Bangkok awaits when you stay at Chatrium Hotel Riverside Bangkok, ideally located in the cultural and historical hub of Bangkok while just 35 minutes from Suvarnabhumi International Airport. Complimentary shuttle boat services make the city's modern and efficient Bangkok Mass Transit System (BTS) a short but pleasant boat ride away. The location is close to the expressway and Central Business district, making both business and leisure activities a pleasure (Chatrium, 2012).

The time when the questionnaires were distributed were "ended of the educational hotel trip". The questionnaire was designed on a scale from 1 to 5 with 5 as "strongly agree" to 1 as "strongly disagree".

Attributes which were considered important and which were assessed included 10 questions to measure the frontline staffs and management team of Chatrium Hotel Riverside Bangkok on their satisfaction of this educational hotel trip as indicated in "finding and discussion".

\section{Finding and Discussions}

The total 50 frontline staffs and management team of Chatrium Hotel Riverside Bangkok as our respondents had replied according to the following 10 questions:

- This program has an appropriated schedule (Date and Time). Regarding this question, the average of the evaluation criteria on a scale from 1 to 5 equal to 4.7 means the frontline staffs and management team of Chatrium Hotel Riverside Bangkok are "agree to strongly agree". Therefore, the program was designed with appropriated timeframe;

- The content of this program is interesting. Regarding this question, the average of the evaluation criteria on a scale from 1 to 5 equal to 4.7 means the frontline staffs and management team of Chatrium Hotel Riverside Bangkok are "agree to strongly agree”. Therefore, the content was designed appropriately;

- I am glad that I have joined and involved in this program. Regarding this question, the average of the evaluation criteria on a scale of 1-5 equal to 4.5 means the frontline staffs and management team of Chatrium 
Hotel Riverside Bangkok are "agree to strongly agree”. Therefore, the hotel staffs were enjoyed to participate;

- I feel comfortable with the program designed. Regarding this question, the average of the evaluation criteria on a scale of 1-5 equal to 4.6 means the frontline staffs and management team of Chatrium Hotel Riverside Bangkok are "agree to strongly agree". Therefore, the hotel staffs were satisfied with the departmental visiting schedule designed by Burapha University International College (BUUIC);

- This program makes interesting contributions to our property, Chatrium Hotel Riverside Bangkok. Regarding this question, the average of the evaluation criteria on a scale of 1-5 equal to 4.35 means the frontline staffs and management team of Chatrium Hotel Riverside Bangkok are "agree to strongly agree". So, the hotel staffs thought that this program was benefited to their property, Chatrium Hotel Riverside Bangkok;

- Burapha University International College (BUUIC) is well organized for their program arrangements. Regarding this question, the average of the evaluation criteria on a scale of 1-5 equal to 4 means the frontline staffs and management team of Chatrium Hotel Riverside Bangkok are "agree”. Therefore, the program was tailor made to the hotel staffs;

- There is a positive climate of teamwork between Burapha University International College (BUUIC) and Chatrium Hotel Riverside Bangkok when handling this program. Regarding this question, the average of the evaluation criteria on a scale of 1-5 equal to 4.5 means the frontline staffs and management team of Chatrium Hotel Riverside Bangkok are "agree to strongly agree”. So, the hotel staffs were satisfied and positive thought regarding cooperation between BUUIC and Chatrium Hotel Riverside Bangkok;

- I am satisfied with this program. Regarding this question, the average of the evaluation criteria on a scale of 1-5 equal to 4.5 means the frontline staffs and management team of Chatrium Hotel Riverside Bangkok are “agree to strongly agree”. Therefore, hotel staffs were more satisfied with the program;

- Overall satisfaction with the program experienced. Regarding this question, the average of the evaluation criteria on a scale of 1-5 equal to 4.85 means the frontline staffs and management team of Chatrium Hotel Riverside Bangkok are "agree to strongly agree". Therefore, the program attributes was well managed, the hotel staffs were experienced and feel delighted;

- All things considered, how would you rate this program so far? Regarding this question, the average of the evaluation criteria on a scale of 1-5 equal to 4.5 means the frontline staffs and management team of Chatrium Hotel Riverside Bangkok are "agree to strongly agree”. According to the hotel staffs rated we found that they were satisfied but some protocols are compulsory to add in order to tailor to our program designations.

\section{Illustrate Table and Figure on Findings and Discussions}

Based on findings and discussion, the information above indicated that the average of answers to find 10 factors of the educational hotel trip. The overall satisfied with the hotel trip which is organized by BUUIC.

Table 1

The Average of the Evaluation Criteria on a Scale of 1-5

\begin{tabular}{ll}
\hline Factor & Score \\
\hline This program has an appropriated schedule (Date and Time) & 4.70 \\
The content of this program is interesting & 4.70 \\
I am glad that I have joined and involved in this program & 4.50 \\
\hline
\end{tabular}


(Table 1 continued)

\begin{tabular}{ll}
\hline Factor & Score \\
\hline I feel comfortable with the program designed & 4.60 \\
This program makes interesting contributions to our property, Chatrium Hotel Riverside Bangkok & 4.35 \\
Burapha University International College (BUUIC) is well organized for their program arrangements & 4.00 \\
There is a positive climate of teamwork between Burapha University International College (BUUIC) & 4.50 \\
and Chatrium Hotel Riverside Bangkok when handling this program & 4.50 \\
I am satisfied with this program & 4.85 \\
Overall satisfaction with the program experienced & 4.50 \\
All things considered, how would you rate this program so far? & \\
\hline
\end{tabular}

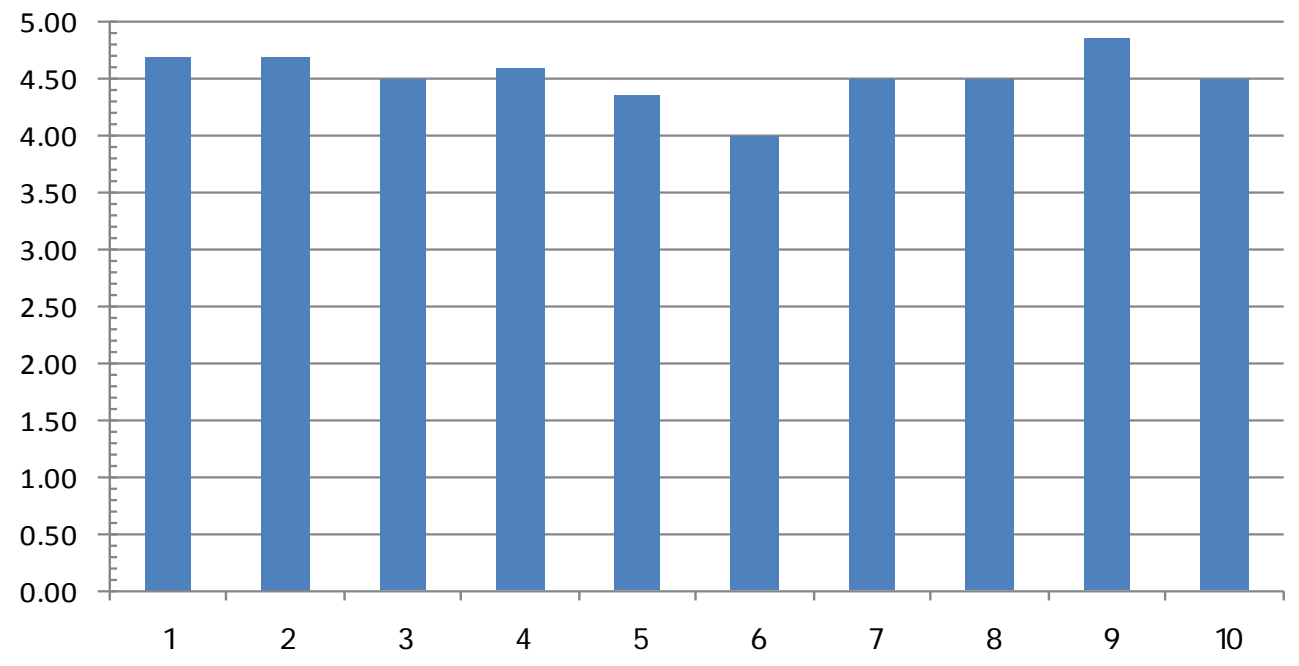

Figure 1. The average of the evaluation criteria on a scale of 1-5.

\section{Conclusions}

As indicated in several studies, educational study trip program evaluation is a systematic approach in identifying strengths and weaknesses of any program, which leads to improvement in educational hotel trips for the benefit to students, lecturers (or) instructors and the frontline staffs and management team of hotel businesses.

The results of the study of satisfaction of hotel business regarding educational hotel trip survey at Chatrium Hotel Riverside Bangkok indicated that in general, the educational hotel trip meets the satisfaction of frontline staffs and management team of Chatrium Hotel Riverside Bangkok. Therefore, this educational hotel trip is well managed and organized with appropriated schedule (date and time), contents, details, and especially, the collaboration between BUUIC and Chatrium Hotel Riverside Bangkok for this successful study trip.

\section{Recommendation for Further Study}

This study attempted to shed light on the factors related to the overall satisfaction of educational trip, further research on possible interactions between these variables might be explored to better understand the relationships between satisfactions with students. Furthermore, areas of next research that would inform the knowledge base of educational trips include studies conducted to understand the experience of university 
students, teachers, hotels' staff and administrators. However, given number of other professionals at colleges and universities that perform educational trip related to this mission who could be considered faculty-like, especially those who teach. Besides that the results of future surveys may be analyzed in the areas of dissatisfaction on departmental operating visit.

Future research on this topic can help support the findings of this research to create a successful educational hotel trip experience for both educational institutions and hotel businesses. In order to promote as the center of ASEAN in educational hotel trip studies, therefore further studies should be concerned with new hotels and new group of people, and additionally the concept of perception and satisfaction of students and educational institutions with linkages to the perspectives of hotel entrepreneurs on educational hotel trip. Moreover, the study of relationship between academic section and the practicum training in hotels also need to be concerned.

\section{References}

Byrne, B. M. (2001). Structural equation modeling with AMOS: Basic concepts, applications and programming. Mahwah, N.J.: Erlbaum.

Chatrium (2012). Chatrium hotel riverside Bangkok. Retrieved March 31st, 2012, from http://www.chatrium.com/chatriumhotel/

Diener, E., \& Suh, E. (1997). Measuring quality of life: Economic, social and subjective indicators. Social Indicators Research, 40, 189-216.

Fornell, C. (1992). A national customer satisfaction barometer: The Swedish experience. Journal of Marketing, 56(1), 6-21.

Hoffman, K. D., \& Bateson, J. E. G. (1997). Essentials of service marketing. London: Dryden.

Johnson, G. M. (2010). What is it that satisfies faculty? Rank as a consideration in factors related to job satisfaction. In Annual Forum of the Association for Institutional Research. Califirnia: ERIC Publication.

Jones, G. R., \& George, J. M. (2011). Essentials of contemporary management. New York, N.Y.: McGraw-Hill Irwin.

Kinicki, A., \& Kreitner, R. (2009). Organizational behavior: Key concepts, skills \& best practices. New York, N.Y.: McGraw-Hill Irwin.

Lee, D., \& Trail, G. (2011). A theoretical model of Team-Licensed Merchandise Purchasing (TLMP). Journal of Research, 6(1), 62-67.

Locke, E. A. (1976). The nature and causes of job satisfaction. In M. D. Dunnette (Ed.), Handbook of industrial and organizational psychology (pp. 1297-1349). Chicago, I.L.: Rand McNally.

Neugarten, B., Havighurst, R., \& Tobin, S. (1961). The measurement of life satisfaction. Journal of Gerontology, 16, $134-143$.

Oliver, R. L. (1981). Measurement and evaluation of satisfaction processes in retail settings. Journal of Retailing, 57(3), $25-48$.

Oliver, R. L. (1999). Whence consumer loyalty? Journal of Marketing, 63(4), 33-44.

Wells, W. D., \& Prensky, D. (1996). Consumer behavior. New York: John Wiley and Sons. 